\title{
Modifikasi Materi Praktikum (Karbohidrat-Enzim) Untuk Meningkatkan Pemahaman Konsep Biokimia Secara Komprehensif dan Efisien
}

\author{
Titik Wijayanti \\ Program Studi Pendidikan Biologi, IKIP Budi Utomo Malang \\ Jalan Citandui 46 Malang \\ e-mail: kititn71@gmail.com \\ Purwaning Budi Lestari \\ Program Studi Pendidikan Biologi, IKIP Budi Utomo Malang \\ Jalan Citandui 46 Malang \\ Purwaning.budilestari@gmail.com
}

\begin{abstract}
Main objectives of this research are to analyze the increase in understanding biochemistry concepts comprehensively caused by practice concept modification (Carbohydate-Enzyme) and analysis the efficiency of practical activities caused by practice concept modification (Carbohydate-Enzyme). Research conducted in September through November 2015 are analytical descriptive research, there are 80 students as respondents were devided into 2 groups of treatment, namely group A as group with practice module that has not been modified and group B with practice module that have been modified. Paired $t$ test result showed that group with practice module were modified to get the score of post-test evaluation better and significantly different than group with practice module that has not been modified. The validation result of practice module by students, instucture, material experts and media experts showed that practice module modified is eligible to used as practical module in the future.
\end{abstract}

Keyword: modification, practice, biochemistry, comprehensive, efficience.

Praktikum biokimia merupakan kegiatan laboratorium yang harus dilaksanakan oleh mahasiswa Program Studi Pendidikan Biologi. Biokimia adalah matakuliah keahlian dan keterampilan (MKK) dengan jumlah sistem kredit semester 3 yaitu 2 sks teori kelas dan 1 sks praktikum laboratorium. Standar kompetensi matakuliah biokimia adalah agar mahasiswa memiliki pengetahuan berkaitan dengan reaksi-reaksi biokimiawi yang terjadi pada metabolisme tubuh makhluk hidup, serta mampu mengembangkan aplikasinya dalam kehidupan sehari-hari. Mengingat standar kompetensi tersebut maka rincian pokok bahasan yang harus disampaikan dalam kegiatan belajar mengajar juga tidak sedikit. Berkaitan dengan metabolisme antara lain karbohidrat, protein, lipid, vitamin, mineral, dan lain-lain. Sementara itu, waktu yang tersedia untuk kegiatan belajar mengajar di kelas hanya 2 kali 50 menit per minggu, dan waktu untuk pelaksanaan kegiatan praktikum adalah 1 sks yang setara dengan 4 kali tatap muka.
Pembelajaran merupakan suatu proses usaha yang dilakukan seseorang untuk memperoleh suatu perubahan tingkah laku yang baru secara keseluruhan sebagai hasil pengalamannya sendiri dalam interaksi dengan lingkungannya (Majid, 2009; Sanaky, 2010). Proses pembelajaran yang baik adalah proses pembelajaran yang di dalamnya menggabungkan kedua faktor di atas, yakni faktor individual dan faktor sosial. Baik faktor sosial atau eksternal (kualitas dan potensi tenaga pengajar serta media pembelajaran yang digunakan) maupun faktor individul atau internal (minat, motivasi dan sikap) mahasiswa. Faktor sikap (attitudinal) mahasiswa ini berkaitan dengan penumbuhan sikap percaya diri, keingintahuan atau ketertarikan mahasiswa terhadap pengetahuan/keilmuan yang disampaikan. Faktor tersebut dapat ditumbuhkan dengan cara melaksanakan dan mengembangkan kegiatan eksperimen atau praktikum.

Kegiatan laboratorium merupakan bagian yang penting dari pembelajaran IPA. Kegiatan 
Laboratorium ditujukan untuk membantu siswa mengembangkan pemahaman, kemampuankognitif, berpikir kreatif, dan sikap ilmiah melalui keterlibatannya dalam hand-on activity. Kegiatan laboratorium menuntut pebelajar berhadapan dengan objek dan permasalahan, memecahkan masalah-masalah itu sampai menemukan kesimpulan yang signifikan dan relevan. Kegiatan laboratorium dalam pembelajaran digunakan untuk mencapai berbagai tujuan yaitu tujuan kognitif, praktikal, dan afektif (Suma, 2005; Kertiasa, 2006). Tujuan kognitif berhubungan dengan belajar konsep-konsep ilmiah, mengembangkan keterampilan problem solving, dan meningkatkan pemahaman metode ilmiah. Tujuan-tujuan praktikal berhubungan dengan pengembangan keterampilan-keterampilan dalam melakukan penelitian-penelitian IPA, analisis data, berkomunikasi, dan keterampilan bekerja sama. Tujuan-tujuan afektif berhubungan dengan motivasi terhadap sains, tanggapan dan kemampuan memahami lingkungan (Sumintono, 2010).

Berdasarkan permasalahan di atas, perlu dilakukan modifikasi materi praktikum yang dapat meningkatkan pemahaman konsep biokimia namun dengan waktu kegiatan pembelajaran yang lebih singkat. Untuk itu dilakukan penelitian dengan judul Modifikasi Materi Praktikum (Karbohidrat-enzim) Untuk Meningkatkan Pemahaman Konsep Biokimia Secara Komperhensif dan Efisien. Tujuan dalam penelitian ini adalah menganalisis peningkatan pemahaman konsep biokimia secara komprehensif akibat modifikasi materi praktikum (Karbohidrat-enzim), dan menganalisis adanya efisiensi kegiatan praktikum akibat modifikasi materi praktikum (Karbohidrat-enzim). Rumusan permasalahan dalam penelitian ini yaitu, apakah modifikasi materi praktikum (Karbohidrat-enzim) dapat meningkatkan pemahaman konsep biokimia secara komprehensif, dan apakah modifikasi materi praktikum (Karbohidrat-enzim) dapat meningkatkan efisiensi kegiatan praktikum.

\section{METODE}

Penelitianinitermasuk dalamjenis penelitian Descriptive Analitik dengan pendekatan metode kuantitatif. Modifikasi materi praktikum (karbohidrat-enzim) selanjutkan akan diujicobakan pada mahasiswa prodi pendidikan biologi IKIP Budi Utomo Malang. Dalam uji coba tersebut digunakan 2 (dua) kelompok, yaitu kelompok A dan kelompok B yang berjumlah 40 orang per kelompok. Penentuan dilakukan secara acak (undian), dan diperoleh bahwa kelompok A adalah kelompok yang diberikan petunjuk praktikum yang belum dimodifikasi, sedangkan kelompok B adalah kelompok yang diberikan petunjuk praktikum yang sudah dimodifikasi. Analisis data yang digunakan dalam penelitian ini adalah Paired T-test (uji t-berpasangan) untuk mengetahui perbedaan hasil evaluasi kelompok A dan kelompok B. Teknik analisis data menggunakan program perangkat lunak komputasi Statistik SPSS v.23 for Windows.

\section{HASIL}

\section{Hasil Kuisioner}

Instrumen kuisioner digunakanuntukmenggali informasi berkaitan dengan penyelenggaraan praktikum biokimia yang selama ini telah dilakukan. Hasil kuisioner diharapkan menjadi petunjuktentangkualitaspelaksanaan praktikum yang telah dilakukan sekaligus menjadi bahan evaluasi, untuk mengetahui hal-hal apa saja yang menjadi kekurangan untuk ditindaklanjuti dengan perbaikan-perbaikan. Sehingga kualitas pelaksanaan praktikum dalam mendukung proses belajar mengajar semakin meningkat dari waktu ke waktu.

Gambar 1 menunjukkan grafik prosentase tentang perlunya praktikum;karbohidratsebagai materi praktikum; waktu-alat dan bahan telah memadai; pentingnya pengenalan karbohidrat; materi penggolongan karbohidrat; materi uji kualitatif; dan pentingnya materi Benedict. Secara keseluruhan hasil kuisioner memberikan pendapat setuju dan sangat setuju. 

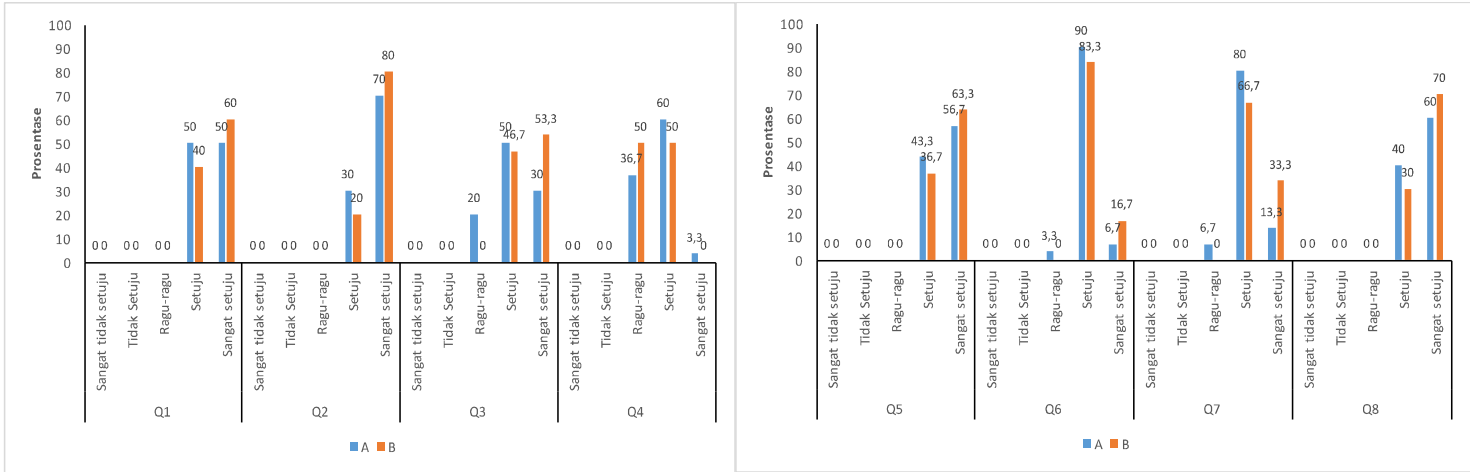

Gambar 1. Grafik prosentase tentang perlunya praktikum, karbohidrat sebagai materi praktikum, waktu alat dan bahan telah memadai, pentingnya pengenalan karbohidrat, materi penggolongan karbohidrat, materi uji kualitatif, dan pentingnya materi Benedict.

Pendapat ragu-ragu sebesar $20 \%$ muncul dari kelompok A yaitu kelompok yang menggunakan petunjuk praktikum lama, yakni pada pertanyaan tentang waktu-alat dan bahan yang digunakan dalam praktikum telah memadai. Selain itu, pendapat ragu-ragu juga muncul pada pertanyaan pentingnya pengenalan karbohidrat. Pendapat tersebut muncul pada kedua kelompok, kelompok A sebesar 36,7\% sedangkan kelompok B sebesar $50 \%$.
Hasil kuisioner tentang pentingnya materi hidolisis amilum enzimatis dan non-enzimatis, serta materi hidrolisis sukrosa enzimatis dan non enzimatis menunjukkan bahwa secara keseluruhan baik kelompok A maupun kelompok B memberikan pendapat setuju dan sangat setuju. Sedangkan untuk pertanyaan penambahan materi enzimatis menambah wawasan dan keterampilan; membandingkan enzimatis dan non enzimatis; efisiensi dan
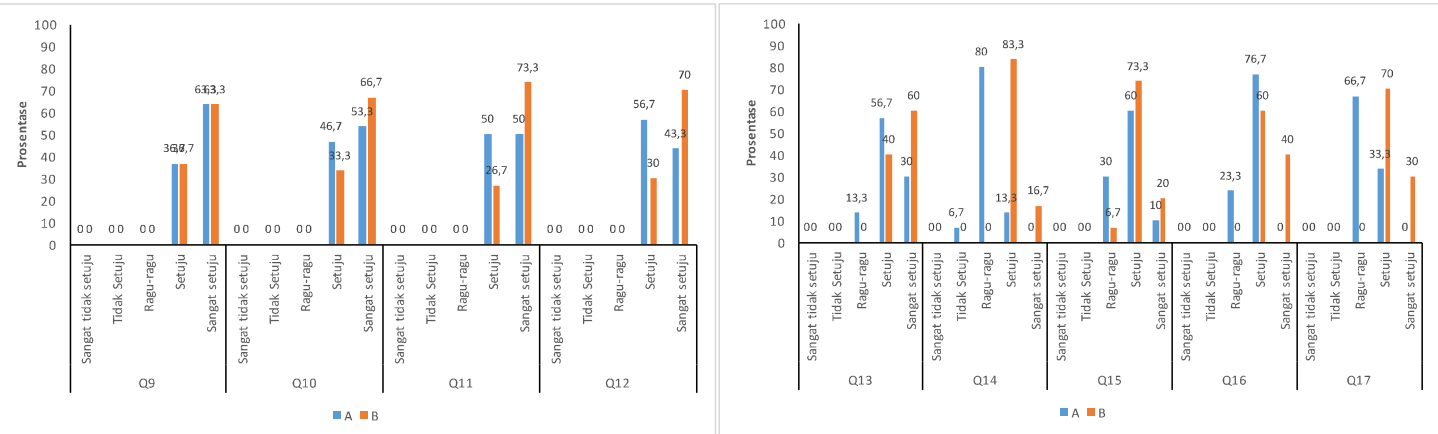

Gambar 2. Grafik prosentase tentang pentingnya materi hidolisis amilum enzimatis dan non-enzimatis, materi hidrolisis sukrosa enzimatis dan non enzimatis, penambahan materi enzimatis menambah wawasan dan keterampilan, membandingkan enzimatis dan non enzimatis, efisiensi dan efektifitas waktu, serta contoh dalam kehidupan sehari-hari.

Gambar 2 menunjukkan grafik prosentase tentang pentingnya materi hidolisis amilum enzimatis dan non-enzimatis; materi hidrolisis sukrosa enzimatis dan non enzimatis; penambahan materi enzimatis menambah wawasan dan keterampilan; membandingkan enzimatis dan non enzimatis; efisiensi dan efektifitas waktu; serta contoh dalam kehidupan seharihari. efektifitas waktu; serta contoh dalam kehidupan sehari-hari, memberikan hasil yang lebih variatif antara ragu-ragu, setuju dan sangat setuju, baik dari kelompok A maupun kelompok B.

\section{Hasil Uji Statistik}

Uji statistik (uji $\mathrm{t}$ berpasangan) dilakukan pada pembandingan nilai pretes antara dua kelompok penelitian. Kelompok A (kelompok 
praktikum dengan petunjuk praktikum yang belum dimodifikasi). Kelompok B (kelompok praktikum dengan petunjuk praktikum yang dimodifikasi).

Uji t berpasangan juga dilakukan pada nilai postes antara dua kelompok penelitian. Kelompok A (kelompok praktikum dengan petunjuk praktikum yang belum dimodifikasi). Kelompok B (kelompok praktikum dengan petunjuk praktikum yang dimodifikasi).
Berdasarkan tabel 2 resume hasil validasi, dapat diketahui bahwa hasil validasi materi memperoleh nilai sangat baik, hasil validasi media memperoleh nilai baik, hasil validasi pengguna/instruktur memperoleh nilai sangat baik, dan hasil validasi praktikan/mahasiswa memperoleh nilai sangat baik. Sehingga ratarata nilai hasil validasi adalah sangat baik.

Tabel 1. Resume Hasil Uji t Berpasangan

\begin{tabular}{llcc}
\hline Bentuk Evaluasi & \multicolumn{1}{c}{ Kelompok } & Rerata & Kesimpulan uji t \\
\hline Pretes & A (Petunjuk praktikum belum dimodifikasi) & 56,93 & Tidak berbeda nyata \\
& B (Petunjuk praktikum dimodifikasi) & 57,40 & \\
\hline Postes & A (Petunjuk praktikum belum dimodifikasi) & 74,86 & Berbeda signifikan \\
& B (Petunjuk praktikum dimodifikasi) & 80,30 & \\
\hline
\end{tabular}

Tabel diatas menunjukkan bahwa baik kelompok A dan B mempunyai kemampuan yang mirip. Hal ini dibuktikan dengan hasil uji $\mathrm{t}$ berpasangan nilai pretes kedua kelompok yang hasilnya tidak berbeda nyata. Tabel juga menunjukkan bahwa terdapat perbedaan hasil nilai postes antara kelompok A dan kelompok B. Rerata nilai kelompok $B$ lebih tinggi dan berbeda secara signifikan dibandingkan kelompok A.

\section{Hasil Validasi Petunjuk Praktikum}

Validasi petunjuk praktikum bertujuan untuk mengetahui sejauh mana kualitas petunjuk praktikum yang digunakan dalam praktikum. Sehingga akan didapatkan input perlunya perbaikan dan bentuk perbaikan yang dilakukan serta inforomasi apakah buku petunjuk praktikum dalam penelitian ini dapat digunakan pada pelaksanaan praktikum dalam proses belajar mengajar secara reguler. Untuk keperluan tersebut, sebagai validator adalah mahasiswa sebagai praktikan (pengguna), instruktur (pengguna), ahli materi, ahli media.

\section{PEMBAHASAN}

Hasil penelitian menunjukkan bahwa responden yang merupakan mahasiswa yang mengikuti praktikum biokimia memberikan respon positif terhadap pelaksanaan praktikum sebagai bagian dari kegiatan belajar mengajar matakuliah biokimia. Hal tersebut dapat dilihat dari jawaban kuisioner yang berkisar pada setuju dan sangat setuju pada butir pertanyaan perlunya praktikum, dan perlunya praktikum karbohidrat.

Hal tersebut dapat dimengerti bahwa praktikum merupakan kegiatan belajar mengajar yang menarikuntuk diikuti.Sehingga mahasiswa antusias dengan adanya pelaksanaan praktikum. Seperti diketahui bahwa kegiatan praktikum akan meliputi perencanaan, perancangan peralatan dan bahan, pengamatan, pencatatan, modifikasi, pembacaan alat pengukur kalibrasi, analisis data, penarikan kesimpulan dan pelaporan (Zainuddin, 1996; Hasrudin, 2012, dan Susanti, 2013). Selain itu praktikum mempunyai beberapa fungsi, yaitu dapat membangkitkan motivasi belajar, mengembangkan ketrampilan

Tabel 2. Resume Hasil Validasi

\begin{tabular}{clc}
\hline No & Aspek & Nilai \\
\hline 1. & Validasi materi & Sangat Baik \\
2. & Validasi media & Baik \\
3. & Validasi pengguna/instruktur & Sangat Baik \\
4. & Validasi praktikan/mahasiswa & Sangat Baik \\
\hline
\end{tabular}


dasar bereksperimen, wahanabelajar pendekatan ilmiah (Zainuddin, 1996; Subiantoro, 2007 dan Hasruddin, 2012).

Hasil penelitian juga menunjukkan bahwa percobaan yang ada di petunjuk praktikum juga ditanggapi dengan positif oleh responden. Hal tersebut dapat dilihat pada butir pertanyaan perlunya percobaan sifat fisik karbohidrat, perlunya percobaan golongan karbohidrat, perlunya uji kualitatif amilum, perlunya uji kualitatif glukosa, perlunya uji hidrolisis amilum secara enzimatis, perlunya uji hidrolisis amilum secara non enzimatis, perlunya uji hidrolisis sukrosa secara enzimatis, perlunya uji hidrolisis sukrosa secara non enzimatis.

Hal tersebut membuktikan bahwa rincian materi percobaan karbohidrat yang tersaji dalam petunjuk praktikum mampu mengakomodasi keingintahuan mahasiswa, kesesuaian materi yang diajarkan di kelas, pengembangan kemampuan dan ketrampilan laboratorium, kesesuaian dengan aplikasi di dunia luar. Hal tersebut penting sekali, sebab materi yang tersaji dalam praktikum haruslah dapat menampung rasa keingintahuan dan motivasi belajar mahasiswa, mampu membangun ketrampilan laboratorium dan eksperimen mahasiswa (Zainuddin, 1996, Hasruddin, 2012).

Materi dalam praktikum harus bersinergi dengan materi yang ada di kelas. Hal ini dikarenakan materi dalam praktikum harus bisa memberi penjelasan secara empirik tentang teori yang disampaikan di kelas. Sinergi yang semacam ini akan membantu pemahaman materi oleh mahasiswa secara utuh. Selain itu materi praktikum harus bisa memberi gambaran sederhana tentang suatu proses yang terjadi dalam dunia nyata. Sehingga memberi gambaran utuh bahwa apa yang terjadi dalam dunia nyata akan ada penjelasan secara ilmiah.

Hasil uji statistik menunjukkan bahwa kemampuan kedua kelompok uji adalah setara. Hal tersebut dapat dilihat dari nilai pretes percobaan karbohidrat kedua kelompok yang tidak berbeda nyata. Hasil uji $\mathrm{t}$ terhadap nilai pretes memberi gambaran bahwa tingkat pengetahuan kedua kelompok penelitian adalah pada tingkat pengetahuan yang setara. Sehingga nantinya jika terjadi perubahan hasil evaluasi praktikum dalam bentuk postes dari kedua kelompok percobaan, maka hal tersebut dipengaruhi oleh materi yang diberikan kepada kedua kelompok.

Hasil uji statistik juga menunjukkan bahwa kelompok yang diberi petunjuk praktikum yang dimodifikasi memberikan hasil nilai postes yang lebih baik dan berbeda nyata dibandingkan kelompok dengan petunjuk praktikum yang belum dimodifikasi. Hasil uji $\mathrm{t}$ terhadap nilai postes kedua kelompok tersebut membuktikan bahwa perbedaan materi praktikum karbohidrat yang diberikan mampu memberikan perbedaan daya serap, keluasan materi dan peningkatan pengetahuan dan ketrampilan mahasiswa yang dicerminkan dalam nilai postes praktikum. Kelompok yang diberikan materi yang lebih baik mendapatkan nilai postes yang lebih baik pula.

Hasil uji validasi buku petunjuk praktikum memperlihatkan bahwa penilaian secara umum dari mahasiswa sebagai praktikan memberikan penilaian sangat baik. Validator ahli media memberikan penilaian baik. Validator ahli materi memberikan penilaian sangat baik. Validator instruktur memberi penilaian secara umum, yaitu sangat baik.

Praktikan memberi masukan yaitu peningkatan sistem praktikum yang lebih baik, dan penambahan fasilitas peralatan laboratorium serta penambahan bahan kimia sebagai penunjang praktikum. Ahli media, sebagai salah satu validator memberikan perbaikan cara penulisan, yang tidak terlalu banyak, yaitu kalimat penghubung. Masukan dari ahli media, adalah perlu penambahan gambar/warna yang menarik. Instruktur memberikan masukan untuk meningkatkan kualitas pelaksanaan praktikum sesuai dengan materi yang sudah direncanakan.

\section{KESIMPULAN DAN SARAN}

Dari hasil penelitian dan pembahasan di atas, maka dapat ditarik kesimpulan sebagai berikut:

1. Mahasiswa memiliki antuasime dan perhatian yang tinggi terhadap pelaksanaan praktikum biokimia yang diselenggarakan baik dari sisi materi percobaan, jadwal pelaksanaan, efisiensi waktu pelaksanaan, peralatan dan bahan percobaan yang disediakan.

2. Mahasiswa memiliki antusiasme dan perhatian yang tinggi terhadap modifikasi materi praktikum (karbohidrat-enzim) dan dapat meningkatkan pemahaman konsep biokimia karbohidrat secara komprehensif.

3. Hasil uji $t$ berpasangan menunjukkan bahwa kelompok yang mendapatkan materi praktikum yang dimodifikasi mendapatkan nilai evaluasi postes yang lebih baik dan 
100 | Titik Wijayanti \& Purwaning Budi Lestari, Modifikasi Materi Praktikum ...

berbeda nyata dibandingkan kelompok dengan materi yang belum dimodifikasi.

4. Hasil validasi petunjuk praktikum oleh praktikan, instruktur, ahli materi dan ahli media menunjukkan bahwa buku petunjuk praktikum yang dimodifikasi layak untuk digunakan sebagai petunjuk praktikum di masa datang.

5. Saran dalam penelitian ini adalah perlunya dilakukankajianuntukmelihatkemungkinan adanya modifikasi materi dalam bab-bab percobaan yang lain yang ada pada petunjuk praktikum biokimia.

\section{DAFTAR RUJUKAN}

Majid, A. 2009. Perencanaan Pembelajaran: Mengembangkan standar kompetensi guru. Remaja Rosdakarya. Bandung.

Sanaky, H. 2011. Media Pembelajaran: Buku Pegangan Wajib Guru dan Dosen. Kaukaba. Yogyakarta.

Suma, K. 2005. Efektivitas Kegiatan Laboratorium Konstruktivis dalam Meningkatkan Penguasaan Konsep-Konsep Arus Searah Mahasiswa Calon Guru. Jurnal Pendidikan dan Pengajaran IKIP Negeri Singaraja. Vol. XVI (2) ISSN: 0215-8250: 159-174.
Kertiasa, N. 2006. Laboratorium Sekolah dan Pengelolaannya. Pudak Scientific. Bandung.

Sumintono, B.; M.A. Ibrahim, dan F.A Dhang, 2010. Pengajaran Sains dengan Praktikum Laboratorium Perspektif dari Guru-Guru Sains di Kota Cimahi, Jurnal Pengajaran MIPA Universitas Teknologi Malaysia. Vol.15 (2): 120-127.

Zainuddin, M. 1996. Panduan Praktikum dalam Mengajar di Perguruan Tinggi. Bagian IV. Program Applied Approach. Jakarta: PAU-PPAI. Direktorat Jenderal Pendidikan Tinggi. Departemen Pendidikan dan Kebudayaan: 13-45.

Hasruddin, dan Rezeqi, 2012. Analisis Pelaksanaan Praktikum Biologi dan Permasalahannya diSMANegeriSekabupaten Karo, Jurnal Tabularasa PPS Unimed. Vol. 9 (1).

Susanti, R. 2013. Pengaruh Penerapan Pembelajaran Berbasis Masalah pada Praktikum Fotosintesis dan Respirasi untuk Meningkatkan Kemampuan Generik Sains Mahasiswa Pendidikan Biologi. FKIP UNSRI. Palembang.

Subiantoro, A.W., 2007. Pentingnya Praktikum dalam Pembelajran IPA. Makalah Pelatihan Pengembangan Praktikum IPA Berbasis Lingkunganbagi Guru-Guru MGMP IPA SMP Kota Yogyakarta. 